\title{
A Review of the Estrous Cycle and the Neuroendocrine Mechanisms in the Mare
}

Satué $\mathrm{K}^{1}$ and Gardón JC

${ }^{1}$ Department of Animal Medicine and Surgery, Cardenal Herrera University, Spain

${ }^{2}$ Department of Experimental Sciences and Mathematics, Catholic University of Valencia "San Vicente Mártir", Spain

\begin{abstract}
With an understanding of basic reproductive science, veterinarians and breeders can be better positioned to achieve their goals. It is important to understand the heat or estrus cycle in order to maximize the chances of success when breeding the mare. Reproductive activity in horses is seasonally dependent, as it is primarily affected by the length of daylight. Therefore the mare has a seasonally polyestrous type of estrous cycle. This means they have breeding season in which they have multiple heat cycles, is receptive to the stallion and ovulates; and a period where they will not go into heat or anestrus. During the anestrus period, most mares show no behavioral signs of sexual receptivity and fail to develop follicles that ovulate. There are exceptions in that a small percentage of mares that do not express a seasonal pattern in that they stay both behaviorally and physiologically receptive to stallions throughout the year. During the ovulatory season, the mare is cycling, thereby exhibiting sexual receptivity to the stallion on a regular basis and is producing follicles that ovulate. The equine estrous cycle is commonly described as a combination of a follicular phase, or estrus, and a luteal phase, or diestrus. The endocrinology of the estrous cycle involves a balance between hormones produced by the pineal gland, hypothalamus, pituitary gland, ovaries, and endometrium. Growth of antral follicles in the ovary occurs in wave-like patterns, and is influenced by several factors such as stage of the estrous cycle, season, pregnancy, age, breed and the individual. In this article will describe the neuroendocrine mechanisms related to breeding seasonality, the hormonal changes that occur during the estrus cycle as well as the variations among mares in regards to the understanding the physiological mechanisms related with the estrous cycle in the mare.
\end{abstract}

Keywords: Endocrinology; Estrous cycle; Mare

\section{Introduction}

The mare is a "seasonally polyestrus" female, meaning that she undergoes regular estrus cycles during a portion of the year and none at others. This is nature's way of preventing the arrival of a foal during bad weather. These cycles are controlled by the mare's hormones, which in turn respond to an increase or decrease in daylight duration with the onset of spring or fall, which affects the pineal gland. The normal estrous cycle in the mare is 21 to 22 days long as defined by the intervals between ovulation. Estrus is the time the mare is "hot", or it is the "follicular phase", as the overt signs of estrus are attributable to the estrogen production by the follicle on the ovary. The duration essentially varies with time of year and is inversely proportional to day length, which means it becomes shorter at the peak of the cycling season. The duration of estrus, however can vary ( 3 to 9 days), so the most regular period in the estrous cycle is the length of diestrus. Diestrus or the luteal phase is dominated by progesterone produced by the corpus luteum has a duration of 14 day (hormonal) or 15 day (behavioral). It is important to understand that there is a closely linked feedback system between many of the reproductive hormones present in the mare which will alter the level or presence of some hormones as levels of other different hormones increase or decrease. This means that many hormonal changes do occur naturally, but when something becomes unbalanced either naturally or artificially, we can see estrous cycle problems develop in the mare. For this reason the mare is unique compared to the other livestock species because the estrous cycle differs between individuals and between cycles in the same individual. Consequently, to be successful in the breeding of horses is essential that owners of mares and technicians understand the reproductive cycle of the mare.

\section{Reproductive Seasonality in the Mare}

From the viewpoint of breeding, the mare is defined as a seasonally polyestrous of long days, or positive phototropic in which breeding activity is regulated directly by the photoperiod. The photoreceptors of the retina capture light stimulus information and transform it into nerve impulses. The nerve impulse is transported through the optic nerve to the suprachiasmatic nucleus and then to the superior cervical ganglion. This last ganglion has adrenergic neuronal endings reaching the pineal gland where the neurotransmitter serotonin is released. Through $\mathrm{N}$-acetyl serotonin, serotonin is transformed into $\mathrm{N}$-acetilserotonina, also called normelatonina. Normelatonina together with the $\mathrm{N}$-acetilserotonina o-methyltransferase (ASMT) involved in the synthesis of melatonin [1].

Melatonin is released during the hours of darkness, following a pattern of secretion inversely proportional to the amount of daylight hours. As a result of increased exposure to photoperiod in the spring and summer, the secretion of melatonin decreases, which in turn stimulates the release of gonadotropin-releasing factor $(\mathrm{GnRH})$ in the hypothalamus. The GnRH enters the hypothalamic-pituitary portal vascular system, and then transported to the adenohypophysis [2], place were follicle stimulating hormones (FSH) and luteinizing hormone (LH) are synthesized. Both gonadotropins are transported through the blood to the ovary place where specifically exert their

*Corresponding author: Katy Satué, Department of Animal Medicine and Surgery, School of Veterinary Medicine, University CEU-Cardenal Herrera, Av. Seminary, s/n, 46113 Moncada, Valencia, Spain, Tel: +34-961369000; Fax: +34-961-39-5272; E-mail: ksatue@uch.ceu.es

Received June 11, 2013; Accepted July 15, 2013; Published July 22, 2013

Citation: Satué K, Gardón JC (2013) A Review of the Estrous Cycle and the Neuroendocrine Mechanisms in the Mare. J Steroids Horm Sci 4: 115. doi:10.4172/2157-7536.1000115

Copyright: ( 2013 Satué K, et al. This is an open-access article distributed under the terms of the Creative Commons Attribution License, which permits unrestricted use, distribution, and reproduction in any medium, provided the original author and source are credited. 
functions [3,4]. FSH acts on the granulosa cells of the preovulatory follicle stimulating the growth, follicular maturation and estrogen biosynthesis. On the theca cells, LH is involved in oocyte maturation, ovulation, establishment and maintenance of corpus luteum (CL) as well as development and in the synthesis of P4. Both ovarian steroids control the Hypothalamus-Hypophysis axis (HHA) by feedback mechanisms that determine the estrous cycle in the mare [5-7].

Changes in the length of photoperiod determine reproductive seasonality in the mare, establishing a character circannual reproductive cycle integrated in turn by four periods differing endocrine and physiologically: spring transition period, ovulatory season or breeding season, autumn transition and winter anestrus $[8,9]$.

The spring transition period is occurs after winter anestrus in early spring due to the increased number of hours of daylight or photoperiod, and ends after a period of two months, with the onset of reproductive activity fertile regular feature ovulatory station. Although this period is of great variability both in features and duration, mares show a pattern of erratic sexual activity, characterized by the presence of irregular and long estrous [9].

The increase of FSH at the beginning of this period causes smaller follicular waves, characterized by the development of multiple follicles from 6 to $21 \mathrm{~mm}$ of diameter, that regress simultaneously in absence of a dominant follicle [10,11]. Low levels of estradiol-17 $\beta$ (E2) and inhibin, due to the absence of preovulatory follicles, simultaneously inhibit the negative feedback on FSH so that gonadotropin levels remain high. However, the seasonal LH deficiency results in low concentrations of E2, inhibin and other factors present in the follicular fluid as the insulin-like growth factor 1 (IGF-I), causing ovulatory failure. Therefore, when performing rectal palpation or ultrasound examination is often the occurrence of various small antral follicles of similar size $(20-30 \mathrm{~mm})$ in the ovary [5]. Due to the influence of photoperiod, the end of spring transition period is represented by larger follicular waves which develop a set of follicles. Most of these follicles undergo atresia but one reaches a larger size than the others. Increasing concentrations of E2 by the preovulatory follicle induced LH surge, leading to first ovulation, indicating the onset of ovulatory season at which fertile cyclical activitybegins [9].

The ovulatory season or breeding season runs from April to September in the northern hemisphere and from October to March in the southern hemisphere. The beginning of the reproductive period occurs when the number of hours of light is adequate to suppress the inhibitory reflex of melatonin on GnRH. GnRH secretion is continuous, pulsed every hour during estrus and every two hours in diestrus. On each estrous cycle may have one or two major follicular waves under uni-or bimodal pattern of FSH secretion. The bimodal pattern occurs specifically at the beginning of the ovulatory season, while the middle or end of this period showed a unimodal pattern $[12,13]$. In contrast to the transition period, characterized by lower follicular waves, in the breeding season follicular waves develop larger, leading to the formation of a dominant follicle. The influence of these hormonal patterns, determines some variability on the duration of the cycles. In North Hemisphere, estrual cycles become more durable at the beginning (April or May), that the end of the breeding season (June or July). It has been hypothesized that the purpose of reproductive seasonality is to ensure the births in the most favorable time of the year, with better environmental conditions and food availability, for the proper development of the foal $[8,9]$.

The high temperatures and decreased influence of photoperiod in late summer, promote the onset of autumn transition period, which in the northern hemisphere covers the months from October to December. Both environmental factors involve a series of gradual changes intended to temporarily end with the activation of antral follicles and the ovulatory process. FSH returns to present a bimodal pattern, as the onset of the breeding season, with a discharge rate of one pulse every two days, so that the diameter of the largest follicle decreases gradually as the period progresses and with it the E2 synthesis [14]. This decrease in estrogens inhibits the preovulatory surge of $\mathrm{LH}$ culminating in the absence of follicular growth and ovulation arrest in early winter $[8,15]$.

The loss of ability to cycle in mares in anestrus is given by the limited influence of photoperiod on gonadotropin levels and covers the months of December, January and mid-February in the northern hemisphere. The increasing number of hours of darkness during the winter promotes the release of high concentrations of melatonin, while blocking the Hypothalamus-Hypophysis-Gonadal axis (HHGA). Thus, GnRH secretion becomes pulsatile with very low amplitude and frequency, being not enough to stimulate the secretion of gonadotropins FSH and LH [3]. Performing rectal palpation ovaries showed small and hard due to the absence of follicles larger than $15 \mathrm{~mm}$. The uterus loses muscle tone and becomes flaccid. Sometimes, we prefer to call this stage as anovulatory and not as anoestrus, because some mares show signs of heat due the release of estrogen by the adrenal glands [9].

Additionally, these seasonal patterns may change under a wide variety of factors such as, temperature, latitude, geographic region, race, age, physiological status, presence of stress and disease, body condition, feeding, among others $[16,17]$.

\section{Estrous Cycle in the Mare}

The estrous cycle is defined as the interval of time between two consecutive ovulations. The approximate length varies between 18 and 22 days, considering on average a period of 21 days $[18,19]$. The current nomenclature stipulates that the estrous cycle consists of two clearly differentiated stages: estrus or follicular phase and diestrus or luteal phase. These phases are characterized by internal modifications of the sexual organs and glandular system as well as behavioral alterations based on the dominant levels of E2 and P4 in each of them, respectively $[8,9]$.

\section{Follicular phase}

Estrus, heat or follicular phase is characterized by the presence of follicles at different stages of development, and the simultaneous increase in the secretion of E2. It has duration about 5-7 days, with a variability of 3-9 days related to the season. Thus, estrus is extended in autumn (7-10 days) and is shortened considerably, in late spring and early summer (4-5 days). During this period the mare is sexually receptive to the stallion genital tract and is ready to receive and transport of sperm and finally culminates with ovulation $[8,19,20]$.

Follicular dynamics: Follicular growth pattern and ovulation: Ovarian follicular development is a complex dynamic process, characterized by marked proliferation and differentiation of follicular cells, providing an optimal environment for oocyte maturation and preparation for fertilization after ovulation [21]. Among the recruited follicles in each follicular wave, dominance take place and one follicle of the cohort acquires the ability to continue growing while others undergo atresia. The regulation of each wave and follicular selection involves interactions between specific circulating gonadotropins and intrafollicular factors, ensuring that each follicle is properly stimulated to grow or regress at any stage of development [22]. 
From an experimental point of view, the occurrence of a wave is defined as follicular growth or simultaneous emergence of a variable number of follicles below 6 to $13 \mathrm{~mm}$ in diameter [23,24]. In the mare, these follicular waves are classified depending on their ability to develop the dominant follicle (primary waves) or, in contrast, generate only small follicles (smaller waves). Thus, the main waves or greater originate several follicles subordinate and a dominant follicle, while smaller waves, the follicles are not larger than $30 \mathrm{~mm}$ in diameter and then regress $[10,11,25,26]$.

During each cycle produces 1 or 2 major follicular waves, differentiated according to time of onset at primary and secondary. The primary major wave occurs near the middle of diestrus, in which the dominant follicle ovulates at the end or near the end of estrus. The largest wave precedes the previous secondary and emerges during late estrus or early diestrus. Basically, there are two anovulatory follicular waves followed by an ovulatory surge during the estrous cycle [14,27]. In horses, there are profound differences in the pattern of follicular waves related to breed. Thus while Quarter Horse mares and ponies usually develops at late diestrus main wave, which culminates with ovulation during estrus in thorough bred mares secondary wave occurs at early diestrus in which the dominant follicle may ovulate, become hemorrhagic or undergo atresia $[25,28]$.

Pierson [13] described the importance of the participation of the gonadotropins FSH and $\mathrm{LH}$ in follicular development. Antral follicles acquire receptors for $\mathrm{LH}$ and FSH at the level of membranes of granulosa cells and theca, respectively. Theca cells under the prevalence of androgen synthesize LH, which will then be aromatized to estrogen by granulosa cells, previously stimulated by FSH. Increased concentrations of estrogen stimulate the secretion of $\mathrm{LH}$, which in turn induces greater estrogen synthesis. This progressive increase in estrogen also promotes the onset of $\mathrm{LH}$ receptors in granulosa cells, which facilitates the transition from the antral stage to preovulatory stage, when the oocyte reaches the final stage of maturation. At 6 days after the emergence of major follicular wave deviation occurs. This event relates to the growth rate difference of the preovulatory follicle size $(22.5 \mathrm{~mm})$ compared to the subordinate follicles $(19 \mathrm{~mm})$ $[11,29,30]$. Deviation is related to inhibin secretion [26] and IGF-1 $[10,31]$. Specifically, inhibin reduces FSH secretion to baseline levels, making it impossible to continue the development of the subordinate follicles $[23,25]$. However, the dominant follicle continues to grow at a constant rate of $2.3 \mathrm{~mm}$ per day until reaching a size of $40 \mathrm{~mm}$ in response to the increased sensitivity to FSH. As has been mentioned, at this stage of development, granulosa cells also develop receptors for $\mathrm{LH}$ required for final oocyte maturation and ovulation after the $\mathrm{LH}$ surge $[32,33]$.

The maximum diameter of the ovulatory follicle usually varies between $40-45 \mathrm{~mm}$ in different horse breeds such as Quarter Horse, Arabian, Thoroughbred and Spanish Purebred [34-37], although the range may be higher ( 30 a $70 \mathrm{~mm}$ ) [9,37]. However, in breeds with a weight below $350 \mathrm{~kg}$ or low height at withers, usually the size of the follicles has a smaller diameter $(35-40 \mathrm{~mm})[16,38]$. Moreover, size differences were established in relation to the breeding season or the presence of multiple ovulations. Therefore, follicles reach a size of 8.5 $\mathrm{mm}$ larger in the spring than in summer or autumn and are $4.9 \mathrm{~mm}$ smaller in multiple ovulations compared to single [16,37].

The highest concentrations of estrogen secreted by the granulosa cells of the preovulatory follicle also induce the appearance of typical behavioral manifestations of estrus. Estrogens are also responsible for reproductive changes that ensure the reception, transport of sperm and oocyte fertilization $[8,18]$. After the preovulatory LH surge, ovulation occurs spontaneously 24-48 hours before the end of the follicular phase. The ovulatory process brings rapid evacuation of the oocyte and follicular fluid after follicular rupture at ovulation fossa. Once completed, E2 concentrations return to basal levels and at the same time completing the oestrus behavior in mares [24,28,33,38-40].

Modifications of behavior and reproductive tract during estrus in mares: The predominance of estrogens during the follicular (proliferative phase) is responsible for behavioral changes and reproductive tract during estrus in the mare. Among the external signs of estrus are described, restlessness and irritability, stallion search, lateral tail lift, frequent urination, mucus secretion, vulvar flicker and clitoral eversion. Also they emphasize relaxation of the head and facial muscles, descent of the pelvis and hind limbs separation to address and accommodate the penis at the time of copulation $[8,18]$

The colposcopic examination can detect longitudinal diameter increase of the vulva, congestion and edema of vulvar and vaginal mucosa $[8,18,41]$. The cervix is open, relaxed, limp and edematous observing the output of mucus with fluid consistency $[8,18]$. Increased vascularization under the dominance of estrogen causes absence of tone at cervix, body and uterine horns, detectable by rectal palpation. Follicular growth becomes appreciable by increased ovarian size and tone [41], which during the week prior to ovulation increases linearly at a rate of $2.7 \mathrm{~mm}$ per day [12]. However, $24-48 \mathrm{~h}$ before ovulation the follicle can lose tone and stop its growth, a fact that occurs in a high percentage of mares $(40 \%)$ day $[12,42]$. Uterine tone does not have specific modifications until the time of ovulation $[8,18]$, although the follicular wall collapse after breaking can be identified as a depression in the ovarian surface [43]

Ultrasound examination of the body and uterine horns exhibits a characteristic heterogeneous pattern comprising alternating echogenic and hypoechoic areas, closely related to the increase of estrogen [44]. Echogenic areas correspond to the inner portions of the endometrial folds while echogenic portions are indicative of the presence of edema at the submucosa. From time to time may appear small amount of free fluid intrauterine physiological character. In ponies and mares of various breeds like Appaloosa, Quarter Horse, Thoroughbred, Dutch Warmblood, Standard bred, endometrial folds become visible 7-8 days prior, progressively increasing the day of ovulation. At the level of the uterine horns are characteristic ultrasound images in a "cart wheel "pattern related to the presence of edema and hypertrophy of the endometrial folds [45]. Using ultrasound monitoring can also be detected muscle contraction in cervix, body and uterine horns and fallopian tubes during the estrous $[8,18]$. After ovulation, endometrial edema disappears and folds are undetectable [12,44-47].

Ovarian ultrasound shows a variable number of follicles from anechogenic consistency that can vary in size according to the time of development $[8,18,19,41,48]$. Preovulatory follicle exhibits pronounced morphological changes, varying spherical or pear-shaped to conical in $84 \%$ of the pre-ovulatory period while the remaining follicles maintained the spherical shape [12]. The follicular wall collapse after the break can also be detected by ultrasound as a hyperechoic irregular area at the cortical region of the ovary [43].

\section{Diestrus or luteal phase}

The diestrus or luteal phase begins at the time of ovulation with the formation of CL, which is responsible for the synthesis of progesterone $\left(\mathrm{P}_{4}\right)$. Unlike the follicular phase the insensitivity of the CL photoperiod 
makes the length of this period more constant. In fact, most research estimates an average duration of 14-15 days, but can be more durable in mid-summer (16 days) than in spring or autumn (13 days) $[8,19]$.

Formation of CL: The disorganization of the follicular wall after ovulation allows blood vessels and fibroblasts invade the follicular cavity. Luteinization involves structural and functional changes of granulosa cells. These are the same cells that initially produced E2 and become into luteal cells that produce $\mathrm{P}_{4}$. The $\mathrm{P}_{4}$ remains high from day 5 post ovulation until the end of the diestrus and exerts specific functions related to the preparation of the endometrium to accept and maintain pregnancy, endometrial gland development and inhibition of myometrial contractility [38].

Have been described two types of CL regarding the presence or absence of central blood clot. In a high percentage of cases (50-70\%) in place of ovulation a core clot develops surrounded by luteal tissue. This type of condition is defined as corpus hemorrhagic. The cavity begins to fill with blood, fibrin and transudate for the first 24 hours, reaching the maximum size at 3 days. Around day 5 post-ovulation CLs that develop central cavity, usually have a significantly higher size $(32.8 \mathrm{~mm})$ to those without it $(26.0 \mathrm{~mm})$. The ratio of the maximum diameter of the CL is 65 to $80 \%$ compared to pre-ovulatory follicle size and has an outer wall thickness of 4-7 mm corresponding to the portion of luteinized tissue. As happens with the size, texture also changes depending on the type of CL. While the corpusluteum that develop central cavity are denser, those who do not have tend to be spongier [49]. Generally, the ratio of non-luteal luteal tissue of the corpus hemorrhagic is minimal during early diestrus and maximum in halfway of diestrus. These events are associated with the gradual decrease of fluid as a result of production and organization of connective tissue associated with the clotting mechanism [50,51]. Notably, the formation of one type or another of $\mathrm{CL}$ is a random event. In fact, the morphology luteal repeatability is not always observed in subsequent ovulations [12,50,51].

Additionally, continuous $\mathrm{P}_{4}$ levels during diestrus reduce the frequency and intensity of GnRH pulses by feedback mechanism. However, because the pulses of FSH are higher than those of LH, a new follicular wave is developed during this period. At the experimental level, cross sections have been made in the ovary in the middle of diestrus, showing alternation of CL and follicles at various stages of development that can reach a variable size $(2-30 \mathrm{~mm})$ or return. In the absence of pregnancy the end luteal phase culminates with the lysis of CL induced by the PGF2 $\alpha$ of endometrial origin and decreased concentrations of $\mathrm{P}_{4}[8,19]$. Luteal regression involves a number of structural and functional events characterized by decreased vascularization, increase of connective tissue, hyalinization, atrophy and fibrosis [43].

Modifications of behavior pattern and reproductive tract during diestrus in mares: During diestrus (secretory phase) the domain of $\mathrm{P}_{4}$ induces behavioral changes and tubular genitalia, characterized by loss of edema and estrus behavior, characteristic of the follicular phase. During this period there are frequent vocalization reflexes of the mare or I kick attacks to prevent the approach of the stallion [8].

By colposcopic examination, the mucosa of the vulva, vagina and cervix appear pale, dry, with small amount of viscous mucus appearance. The longitudinal diameter of the vulva is shortened and the cervix appears closed, pale and centrally $[8,19]$.

On rectal palpation the cervix, body and uterine horns are firm, narrow and tubular although uterine tone is lower than during gestation. Although it is difficult to explore, the CL could be identified during the first few days post-ovulation, although developing follicles (diameter less than $25 \mathrm{~mm}$ ) would not be identifiable [43].

The ultrasound of the uterus shows a homogeneous pattern marked by the lack of endometrial folds and the presence of a small amount of intrauterine fluid $[46,52,53]$. While the luteal tissue is observed hypoechoic, the echogenicity increases in the connective tissue of the ovarian stromal. Although the diameter of the body is higher than hemorrhagic $\mathrm{CL}$ without central cavity, the ratio of luteal tissue is similar in both types [46,50-53]. Echogenicity pattern varies according to the period of development and growth or regression of the CLsince it is inversely related to the degree of vascularization [37,51]. Furthermore, these changes in the pattern of endometrial and luteal echotexture are closely related to $\mathrm{P}_{4}$ levels [54]. Thus, the gradual increase in $\mathrm{P}_{4}$ that characterized the early diestrus is associated with increased diameter and luteal vascularization and decreased echogenicity. The highest concentrations of $\mathrm{P}_{4}$ that define the half of diestrus are related to the diameter and maximum vascularization and minimum echogenicity. The regression of the $\mathrm{CL}$ and $\mathrm{P}_{4}$ decrease structurally correspond with decreased luteal area and vascularization and increased echogenicity. The corpus luteal is visible by ultrasound until day 17 of the cycle [55]. These structural changes precede functional variations during the maturing period and luteal regression [37,56-58].

\section{Endocrinological Aspects Related with the Estrous Cycle in the Mare}

Physiological events that occur during the estrous cycle are regulated by the coordinated interaction of various hormones and releasing factors like $\mathrm{GnRH}, \mathrm{FSH}, \mathrm{LH}, \mathrm{E} 2, \mathrm{P}_{4}$ and prostaglandin $\mathrm{F}-2 \mathrm{a}$ (PGF2 $\alpha$ ), among others [2] (Figure 1). Here are described the most notable changes that everyone has and the physiological involvement during the estrous cycle in the mare.

\section{Gonadotrophin releasing factor}

As has been discussed previously, increased photoperiod during spring and summer causes decreased secretion of melatonin. This signal has a positive effect on the pulses of hypothalamic GnRH, which in turn controls the release of gonadotropins [12]. GnRH pulses produced every $45 \mathrm{~min}$ originate predominantly LH secretion whereas those occur every $6 \mathrm{~h}$. stimulate the secretion of FSH. The high frequency pulses of $\mathrm{GnRH}$ ( 2 pulses per hour) during estrus favors an increase in LH and FSH decline, while reducing the frequency to 2 pulses per day, leads an increase of FSH and LH inhibition [3]. These endocrine events, allowing the emergence of follicular waves, E2 synthesis and ovulation during estrus and appearance of the $\mathrm{CL}$ with $\mathrm{P}_{4}$ release during diestrus [38].

\section{Follicle stimulating hormone}

As has been discussed, FSH describes two types of secretion patterns during the estrous cycle in the mare: uni or bimodal. The bimodal pattern occurs frequently during the spring transition period and ovulatory season. The first peak of FHS appears between the 8th and 14th day of the cycle, moment in which the largest follicle reached a diameter of $13 \mathrm{~mm}$ [59]. This initial increase precedes the beginning of the deviation and is associated with increased synthesis of inhibin by the largest follicle $[10,11,59-62]$ and persists until the preovulatory follicle reaches a diameter of $22 \mathrm{~mm}$. The second peak of FSH begins on day 15 of the cycle and it is necessary to complete the development of the preovulatory follicle $[23,59,61]$. Unlike the bimodal pattern, the first peak of FSH would be absent in the unimodal pattern [63]. In the 


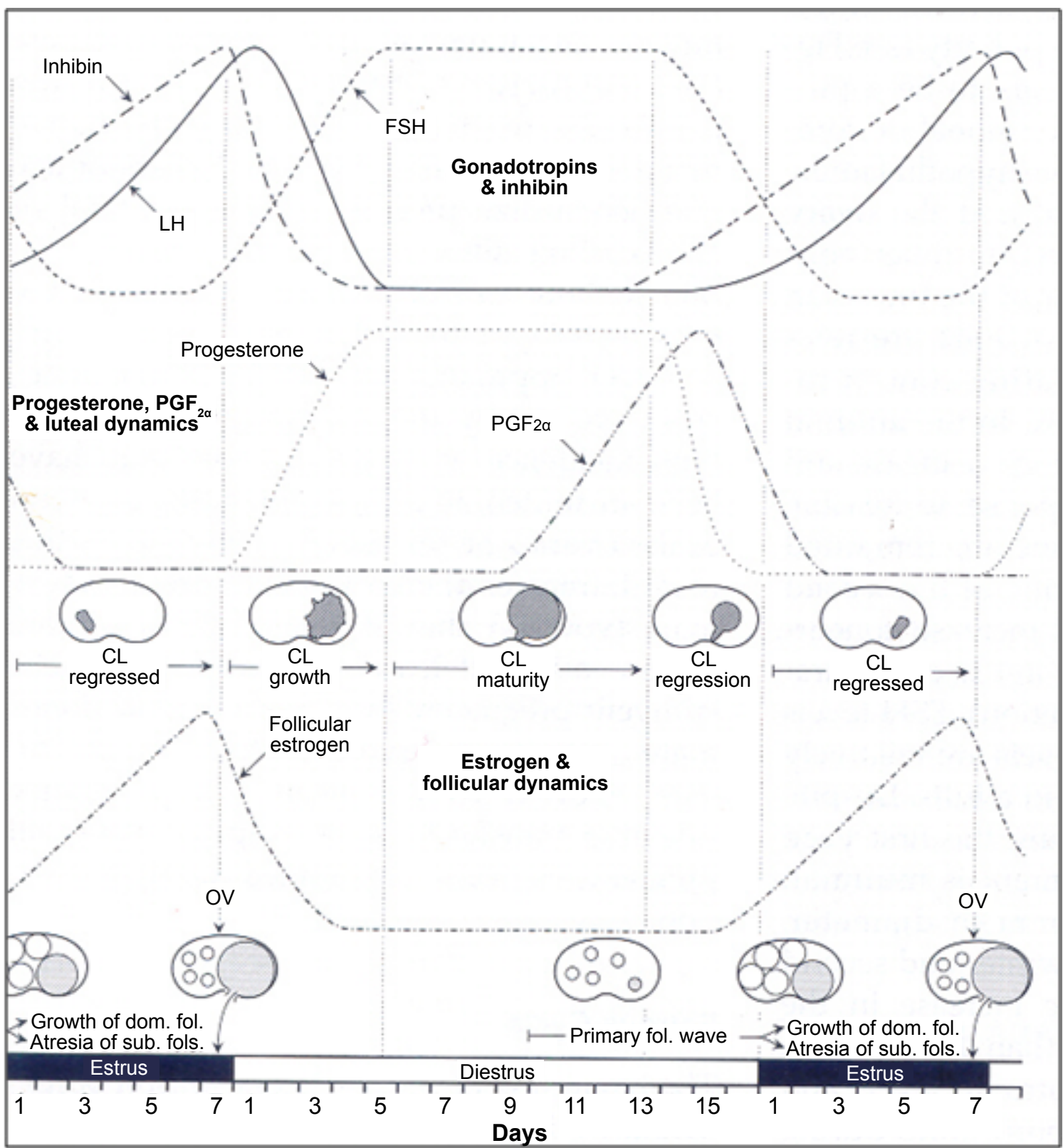

Figure 1: Hormone profiles and temporal relationships with follicular and luteal development during the oestrous cycle in the mare (Adapted from Ginther OJ (1992) Reproductive Biology of the Mare: Basic and Applied Aspects.(2nd edn). Cross Plains, WI: Equiservices Publishin).

latter pattern FSH levels remain low during estrus, rise in times around ovulation, maintaining increased during diestrus [61].

FSH is also involved in the development of the $\mathrm{LH}$ receptors in the preovulatory follicle $[4,64]$. At the start of follicular growth, low levels of estradiol exert a negative feedback on HHA controlling the tonic or basal release of gonadotropin. This mechanism controls the follicular growth and E2 synthesis continuously preventing ovarian overstimulation. After the period of follicular growth, once the dominant follicle has been selected, the E2 and inhibin levels are significantly increased. This elevation of E2 is responsible for the characteristic changes of the genital tract and signs of heat during estrus. Furthermore, this response exerts a positive feedback on the HHA, favoring the emergence of preovulatory LH surge, necessary to produce the ovulation. Additionally, the stimulatory effects of E2 on LH combined to the inhibitory action of inhibin on FSH create the ideal microenvironment for the final maturation of the oocyte, inhibiting the development of immature follicles [18].

\section{Luteinizing hormone}

LH levels gradually increases from day -5 to day of ovulation, when it reaches the maximum concentration $[9,65]$. As already mentioned, the pre-ovulatory LH surge occurs as a result of the positive feedback mechanism exerted by E2 concentrations secreted by the granulosa cells of the preovulatory follicle in the adenohypophysis. However, the peak of E2 is reached 2 days before the LH. During diestrus LH is released in a pulsatile manner, with a frequency of 1.4 pulses per 24 hours and for a period of 20-40 minutes at the central level, or 2-4 h per 
Citation: Satué K, Gardón JC (2013) A Review of the Estrous Cycle and the Neuroendocrine Mechanisms in the Mare. J Steroids Horm Sci 4: 115 doi:10.4172/2157-7536.1000115

Page 6 of 8

pulse at the peripheral level [66], therefore $\mathrm{P}_{4}$ secretion is maintained by basal levels of $\mathrm{LH}$. The decline of $\mathrm{LH}$ at the end of diestrus is a result of the combined effect of decreased estrogen positive feedback, and the resurgence of negative feedback induced by $\mathrm{P}_{4}$ on the HHA. This gonadotropin not only participates in the development and maturation of the primary follicles but also in the development and maintenance of CL during the luteal phase $[10,11,19,33,60]$.

It has been hypothesized that the persistence of high levels of $\mathrm{LH}$ after ovulation could induce ovulation in diestrus, which may occur 3-5 days after the first ovulation. However, these ovulations are not accompanied by signs of heat, an event related to the suppressive effects of $\mathrm{P}_{4}$ on estrous behavior $[38,67]$.

\section{Estradiol-17 $\beta$}

The ability of estrogen synthesis is dependent on the effect of FSH on granulosa cells. In the absence of $\mathrm{P}_{4}$, estrogens begin to be actively secreted by the preovulatory follicle 5-7 days before ovulation. This event coincides with the time of departure and reaches the peak two days before ovulation $[19,33,68]$, and will be responsible for the preovulatory release of LH. After ovulation, E2 levels begin to decrease gradually after $48 \mathrm{~h}$, reaching basal levels at day 5 post-ovulation $[10,11,36,69-71]$.

Although estrogen levels are directly related to the degree of ovarian activity, sexual receptivity and reproductive tract changes during estrus $[8,10,18,44,48,57,61,68,72]$, there is no evidence of a direct relationship between the intensity of endometrial edema and steroid levels. This situation is much clearer on $\mathrm{P}_{4}$. In fact, swelling occurs when $\mathrm{P}_{4}$ levels are less than $1 \mathrm{ng} / \mathrm{ml}$, so this hormone could be responsible in principle on the intensity of edema, among other behavioral and morphological changes of the cervix and uterus $[68,72,73]$. However, at the time of ovulation inverse correlations are established between E2 and FSH levels associated with the negative feedback effect of inhibin, as previously referred [61].

\section{Progesterone}

Steroidogenic activity of $\mathrm{P}_{4}$ depends on the action of $\mathrm{LH}$ on theca cells. As noted above, levels of $\mathrm{P}_{4}$ are lower than $1 \mathrm{ng} / \mathrm{ml}$ during estrus $[12,20,36,68,70]$. After ovulation, increases progressively and significantly to the $5^{\text {th }}$ or $6^{\text {th }}$ day, with values similar to those of pregnant mares during the first 14 days of gestation [74]. At this time the CL is fully functional and $\mathrm{P}_{4}$ levels remain high until day $9[70,72,75]$, consistent with the maximum diameter reached by the CL $[9,37,75]$.

However, peripheral concentrations of $\mathrm{P}_{4}$ are highly variable between mares. This variability is associated with secretory capacity $\mathrm{CL}$ and hormonal catabolic rate. Perhaps this fact may explain the differences in $\mathrm{P}_{4}$ levels between ponies and mares during the first 5 days of the luteal period or between Arabian and Spanish Pure bred mares [34], despite the similarity in length of estrous cycles. Among other factors related to variations in levels of $\mathrm{P}_{4}$ highlights the number of ovulations. In fact, double ovulations induce higher concentrations of $\mathrm{P}_{4}$ compared to simple ones [75].

$\mathrm{P}_{4}$ inhibits the secretion and pulsatile release of $\mathrm{GnRH}$ and $\mathrm{LH}$, but does not modify the pattern of FSH $[8,10,57,73]$. This event, unlike what happens in other species, enabling a new wave of follicular growth and in some cases the presence of ovulations during diestrus related to high levels of this hormone $[18,33,39,58,76]$. After lysis of the CL at the end of diestrus, $\mathrm{P}_{4}$ is drastically reduced to levels below $1 \mathrm{ng} / \mathrm{ml}$, a fact which promotes the mare returns to estrus $[36,70,73,77]$.

\section{Prostaglandin F2}

In the absence of pregnancy the average life span of the CL is controlled by the release of endometrial PGF2 $\alpha$ source, establishing a bimodal pattern of discharge around day 13-16 of diestrus. While the first 4-hour peak precedes the decline of $\mathrm{P}_{4}$, the second occurs during and after luteolysis. Luteolysis involves decreased blood supply, leukocyte infiltration, cell disruption and loss of lutein steroidogenic capacity by apoptotic or non-apoptotic mechanisms intended to disintegrate the $\mathrm{CL}$ and therefore secretion $\mathrm{P}_{4}[58,73,78,79]$.

\section{References}

1. Haimov I, Lavie P (1995) Potential of melatonin replacement therapy in older patients with sleep disorders. Drugs Aging 7: 75-78.

2. Cunningham JG, Klein BG (2009) Veterinary Physiology. (4thedn). Elsevier.

3. Alexander SL, Irvine CH (1991) Control of onset of breeding season in the mare and its artificial regulation by progesterone treatment. J Reprod Ferti Suppl 44: 307-318.

4. Irvine CHG, Alexander SL (1993) Secretory patterns and rates ofgonadotrophinreleasing hormone, follicle-stimulating hormone, and luteinizing hormone revealed by intensive sampling of pituitary venous blood in the luteal phase mare. Endocrinology 132: 212-218.

5. Sharp DC, Davis SD (1993) Vernal transition. In: Equine Reproduction McKinnon, A.O.; Voss, J.L. (eds.). Lea \& Febiger, Philadelphia: 133-143.

6. Evans MJ, Alexander SL, Irvine CH, Kitson NE, Taylor TB (2011) Administration of a gonadotropin-releasing hormone antagonist to mares at different times during the luteal phase of the estrous cycle. Anim Reprod Sci 127: 188-196.

7. Velez IC, Pack JD, Porter MB, Sharp DC, Amstalden M, et al. (2012) Secretion of luteinizing hormone into pituitary venous effluent of the follicular and luteal phase mare: novel acceleration of episodic release during constant infusion of gonadotropin-releasing hormone. Domest Anim Endocrinol 42: 121-128.

8. Crowell-Davis SL (2007) Sexual behavior of mares. Horm Behav 52: 12-17.

9. Aurich C (2011) Reproductive cycles of horses. Anim Reprod Sci 124: 220-228.

10. Ginther OJ, Beg MA, Gastal MO, Gastal EL (2004a) Follicle dynamics and selection in mares. Anim Reprod 1: 45-63.

11. Ginther OJ, Gastal EL, Gastal MO, Bergfelt DR, Baerwald AR, et al. (2004) Comparative study of the dynamics of follicular waves in mares and women Biol Reprod 71: 1195-1201.

12. Ginther OJ (1992) Reproductive biology of the mare: basic and applied aspects (2nd edn) Cross Plains, WI: Equiservices Publishing: 224-226.

13. Pierson RA (1993) Folliculogenesis and ovulation. In: Equine Reproduction. McKinnon, A, Voss J (eds.) Williams \& Wilkins, Media, PA: 161

14. Irvine CHG, Alexander SL, Mckinnon AO (2000) Reproductive hormone profiles in mares during the autumn transition as determined by collection of jugular blood at $6 \mathrm{~h}$ intervals throughout ovulatory and anovulatory cycles. $J$ Reprod Fertil 118: 101-109.

15. Turner DD, Garcia MC, Ginther OJ (1979) Follicular and gonadotropic changes throughout the year in pony mares. Am J Vet Res 40: 1694-1700.

16. Morel MC, Newcombe JR, Hayward K (2010) Factors affecting pre-ovulatory follicle diameter in the mare: the effect of mare age, season and presence of other ovulatory follicles (multiple ovulation). Theriogenology 74: 1241-1247.

17. Vecchi I, Sabbioni A, Bigliardi E, Morini G, Ferrari L, et al. (2010) Relationship between body fat and body condition score and their effects on estrous cycles of the Standardbred maiden mare. Vet Res Commun 34 Suppl 1: S41-45.

18. Bergfelt DR (2000) Estrous synchronization. In: Equine breeding management and artificial insemination. Samper, JC (ed.) Saunders Company, Philadelphia: 165-177.

19. Ginther OJ, Beg MA, Neves AP, Mattos RC, Petrucci BP, et al. (2008) Miniature ponies: 2. Endocrinology of the oestrous cycle. Reprod Fertil Dev 20: 386-390.

20. Squires EL (1993) Embryo transfer. In: Equine Reproduction. McKinnon AO Voss, JL (eds.) Lea \& Febiger, Philadelphia.

21. Armstrong DG, Webb R (1997) Ovarian follicular dominance: the role of intraovarian growth factors and novel proteins. Rev Reprod 2: 139-146. 
Citation: Satué K, Gardón JC (2013) A Review of the Estrous Cycle and the Neuroendocrine Mechanisms in the Mare. J Steroids Horm Sci 4: 115 doi:10.4172/2157-7536.1000115

Page 7 of 8

22. McMeen SL (2002) Follicular growth and development and gonadotropin response of mares treated with dihidrotestosterone and estradiol benzoate. Thesis of Master of Science. Louisiana State University.

23. Ginther OJ, Bergfelt DR (1993) Growth of small follicles and concentrations of FSH during the equine oestrous cycle. J Reprod Fertil 99: 105-111.

24. Ginther OJ, Beg MA, Bergfelt DR, Donadeu FX, Kot K (2001) Follicle selection in monovular species. Biol Reprod 65: 638-647.

25. Ginther OJ (2000) Selection of the dominant follicle in cattle and horses. Anim Reprod Sci 60-61: 61-79.

26. Donadeu FX, Ginther OJ (2002) Changes in concentrations of follicular fluid factors during follicle selection in mares. Biol Reprod 66: 1111-1118.

27. Ginther OJ (1990) Folliculogenesis during the transitional period and early ovulatory season in mares. J Reprod Fertil 90: 311-320.

28. Stabenfeldt SE, Munglani G, García AJ, LaPlaca MC (2010) Biomimetic microenvironment modulates neural stem cell survival, migration, and differentiation. Tissue Eng Part A 16: 3747-3758.

29. Gastal EL, Gastal MO, Bergfelt DR, Ginther OJ (1997) Role of diameter differences among follicles in selection of a future dominant follicle in mares. Biol Reprod 57: 1320-1327.

30. Watson ED, Thomassen R, Steele M, Heald M, Leask R, et al. (2002) Concentrations of inhibin, progesterone and oestradiol in fluid from dominant and subordinate follicles from mares during spring transition and the breeding season. Anim Reprod Sci 74: 55-67.

31. Ginther OJ, Beg MA, Bergfelt DR, Kot K (2002) Activin A, estradiol, and free insulin-like growth factor $I$ in follicular fluid preceding the experimental assumption of follicle dominance in cattle. Biol Reprod 67: 14-19.

32. Gastal EL, Bergfelt DR, Nogueira GP, Gastal MO, Ginther OJ (1999) Role of luteinizing hormone in follicle deviation based on manipulating progesterone concentrations in mares. Biol Reprod 61: 1492-1498.

33. Gastal EL (2009) Recent advances and new concepts on follicle and endocrine dynamics during the equine periovulatory period. Anim Reprod 6: 144-158.

34. Vivo R, Vinuesa M, Rodriguez I (1992) Valoración del desarrollo folicular preovulatorio en yeguas Pura Raza Española y Árabes. Arch Zootec 41: 19-26.

35. Vinuesa M, Vivo R (1993) Diámetro del folículo preovulatorio y vesícula embrionaria en yeguas árabes y pura raza española. Arch Zootec 42: 263-267.

36. Satué K, Montesinos P, Gardon JC (2013) Influence of oestrogen and progesterone on circulating neutrophils and monocyte during ovulatory and luteal phase in healthy Spanish Purebred mares. Proceeding of XIX Congress of Societa Italiana Veterinari per Equini (SIVE): 383-384

37. Bergfelt DR, Adams GP (2007) Ovulation and corpus luteum development. In Current therapy in equine reproduction. Rudolph, P (ed.). Saunders Company Publisher, St. Louis, Missouri: 1-13.

38. Younqquist RS, Threlfall WR (2007) Clinical Reproductive Anatomy and Physiology of the Mare. In: Large Animal Theriogenology. Youngquist RS Threlfall WR (eds.). Saunders Elsevier, St Louis: 47- 67.

39. Donadeu FX, Pedersen HG (2008) Follicle development in mares. Reprod Domest Anim 43 Suppl 2: 224-231.

40. Gastal EL (2011) Ovulation. Part 1. Follicle development and endocrinology during the periovulatory period. In: Equine Reproduction. McKinnon AO, Squires EL, Vaala WE, Dickson DV (Eds.). (2nd edn). Ames, IA: WileyBlackwell: 2020-2031.

41. Samper JC, Pycock JF (2007) The normal uterus in estrous. In: Current therapy in Equine Reproduction. Samper, JC, Pycock, JF, McKinnon AO (eds.) Saunders, St. Louis, Missouri: 32-35.

42. Palmer E, Driancourt MA (1980) Use of ultrasonic echography in equine gynecology. Theriogenology 13: 203-216.

43. Samper JC (2008) Induction of estrus and ovulation: why some mares respond and others do not. Theriogenology 70: 445-447.

44. Pycock JF, Dielman S, Drifjhout P, Van der Brug Y, Oei Y, et al. (1995) Correlation of plasma concentrations of progesterone and oestradiol with ultrasound characteristics of the uterus and duration of oestrous behaviour in the cycling mare. Reprod Dom Anim 30: 224-227.

45. Hayes KE, Pierson RA, Scraba ST, Ginther OJ (1985) Effects of estrous cycle and season on ultrasonic uterine anatomy in mares. Theriogenology 24: 465477

46. Ginther OJ, Pierson RA (1984) Ultrasonic anatomy and pathology of the equine uterus. Theriogenology 21: 505-516.

47. Mckinnon AO, Squires EL, Carnevale EM, Harrison LA, Frantz DD, et al. (1987) Diagnostic ultrasonography of uterine pathology in the mare. Proceeding of 33rd Annual Convention of American Association of Equine Practice: 605-622.

48. Bragg Weber ND, Pierson RA, Card CE (2002) Relationship between estradio $17-\beta$ and endometrial echotexture during natural and hormonally manipulated estrus in Mares. Proceedings A.A.E.P: 41-47.

49. Dickson SE, Fraser HM (2000) Inhibition of early luteal angiogenesis by gonadotropin-releasing hormone antagonist treatment in the primate. J Clin Endocrinol Metab 85: 2339-2344.

50. Bergfelt DR, Ginther OJ (1992) Embryo loss following GnRH-induced ovulation in anovulatory mares. Theriogenology 38: 33-43.

51. Ginther OJ (1995) Ultrasonic imaging and animal reproduction: Fundamentals, Book 1. Ed: Cross Plains, Wl: Equiservices Publishing: 27-82.

52. Montavon S (1994) Ultrasonography of the formation and development of the corpus luteum in the mare: review for the practitioner. Schweiz Arch Tierheilkd 136: 91-94.

53. Plata-Madrid H, Younquist RS, Murphy CN, Bennett-Wimbush K, Braun WF et al. (1994) Ultrasonographic characteristics of the follicular and uterine dynamics in Belgian mares. J Equine Vet Sci 14: 421-423.

54. Ferreira-Dias G, Costa AS, Mateus L, Korzekwa A, Redmer DA, et al. (2006) Proliferative processes within the equine corpus luteum may depend on paracrine progesterone actions. J Physiol Pharmacol 57: 139-151.

55. Burris T (1999) Progestins. In: Encyclopedia of Reproduction. Knobil E, Neill, JD, (eds.) 4, New York: Acedemic Press: 23-30.

56. Bergfelt DR, Brogliatti GM, Adams GP (1998) Gamete recovery and follicular transfer (graft) using transvaginal ultrasonography in cattle. Theriogenology 50 : $15-25$.

57. Bollwein H, Mayer R, Weber F, Stolla R (2002) Luteal blood flow during the estrous cycle in mares. Theriogenology 57: 2043-2051.

58. Ginther OJ (2012) The end of the tour de force of the corpus luteum in mares. Theriogenology 77: 1042-1049.

59. Gastal EL, Gastal MO, Nogueira GP, Bergfelt DR, Ginther OJ (2000) Temporal interrelationships among luteolysis, FSH and $\mathrm{LH}$ concentrations and follicle deviation in mares. Theriogenology 53: 925-940.

60. Ginther OJ, Beg MA, Gastal EL, Gastal MO, Baerwald AR, et al. (2005) Systemic concentrations of hormones during the development of follicular waves in mares and women: a comparative study. Reproduction 130: 379-388.

61. Medan MS, Nambo Y, Nagamine N, Shinbo H, Watanabe G, et al. (2004) Plasma concentrations of Ir-inhibin, inhibin A, inhibin pro-aC, $\mathrm{FSH}$, and estradiol-17ß during estrous cycle in mares and their relationship with follicular growth. Endocrine 25: 7-14.

62. Kenny HA, Woodruff TK (2006) Follicle size class contributes to distinct secretion patterns of inhibin isoforms during the rat estrous cycle. Endocrinology 147: $51-60$.

63. Alexander SL, Irvine CH, Livesey JH, Donald RA (1993) The acute effect of lowering plasma cortisol on the secretion of corticotropin-releasing hormone arginine vasopressin, and adrenocorticotropin as revealed by intensive sampling of pituitary venous blood in the normal horse. Endocrinology 133 860-866.

64. Reichert LE Jr (1994) The functional relationship between FSH and its receptor as studied by synthetic peptide strategies. Mol Cell Endocrinol 100: 21-27.

65. Evans JW, Hughes JP, Neely DP, Stabenfeldt GH, Winger CM (1979) Episodic $\mathrm{LH}$ secretion patterns in the mare during the oestrous cycle. J Reprod Fertil Suppl 143-150.

66. Pantke P, Hyland J, Galloway DB, MacLean AA, Hoppen HO (1991) Changes in luteinizing hormone bioactivity associated with gonadotrophin pulses in the cycling mare. J Reprod Fertil Suppl 44: 13-18.

67. Hughes IA, Dyas J, Robinson J, Walker RF, Fahmy DR (1985) Monitoring treatment in congenital adrenal hyperplasia. Use of serial measurements of 
Citation: Satué K, Gardón JC (2013) A Review of the Estrous Cycle and the Neuroendocrine Mechanisms in the Mare. J Steroids Horm Sci 4: 115. doi:10.4172/2157-7536.1000115

17-OH-progesterone in plasma, capillary blood, and saliva. Ann N Y Acad Sci 458: 193-202.

68. Amer HA, Shawkig G, Ismail R (2008) Profile of steroid hormones during oestrus and early pregnancy in Arabian mares. Slov Vet Res 45: 25-32.

69. Bergfelt DR, Gastal EL, Ginther OJ (2001) Response of estradiol and inhibin to experimentally reduced luteinizing hormone during follicle deviation in mares. Biol Reprod 65: 426-432.

70. Gouraninezhad S, Kohram H, Khajeh GH, Mashhoori M (2006) Estradiol and progesterone changes in estrus cycle of Arabian mare in khouzestan region. Sci Res Ir Vet J 10: 65-71.

71. Ginther OJ, Utt MD, Beg MA (2007) Follicle deviation and diurnal variation in circulating hormone concentrations in mares. Anim Reprod Sci 100: 197-203.

72. Honnens A, Weisser S, Welter H, Einspanier R, Bollwein H (2011) Relationships between uterine blood flow, peripheral sex steroids, expression of endometrial estrogen receptors and nitric oxide synthases during the estrous cycle in mares. J Reprod Dev 57: 43-48.

73. Daels PF, Hughes JP (1993) The normal estrous cycle. In: Equine Reproduction. McKinnon AO, Voss, JL (eds.). Lea \& Febiger, Philadelphia: 121-132.
74. Satué K, Domingo R, Redondo Jl (2011) Relationship between progesterone oestrone sulphate and cortisol and the components of renin angiotensin aldosterone system in Spanish purebred broodmares during pregnancy. Theriogenology 76: 1404-1415.

75. Nagy P, Huszenicza G, Reiczigel J, Juhász J, Kulcsár M, et al. (2004) Factors affecting plasma progesterone concentration and the retrospective determination of time of ovulation in cyclic mares. Theriogenology 61: 203-214.

76. Irvine CH, Turner JE, Alexander SL, Shand N, van Noordt S (1998) Gonadotrophin profiles and dioestrous pulsatile release patterns in mares as determined by collection of jugular blood at $4 \mathrm{~h}$ intervals throughout an oestrous cycle. J Reprod Fertil 113: 315-322.

77. Kelley D (2009) The effect of moderate exercise on folliculogenesis, cortisol estradiol and luteinizing hormone in mare. Doctoral Thesis. School of Clemson University:1-119.

78. Shand N, Irvine CH, Turner JE, Alexander SL (2000) A detailed study of hormonal profiles in mares at luteolysis. J Reprod Fertil Suppl : 271-279.

79. Ginther OJ, Beg MA (2011) Hormone concentration changes temporally associated with the hour of transition from preluteolysis to luteolysis in mares. Anim Reprod Sci 129: 67-72. 